Louisiana State University

LSU Digital Commons

Faculty Publications

Department of Biological Sciences

6-1-2016

\title{
Variation in the whole mitogenome of reef-building Porites corals
}

David A. Paz-García

Centro de Investigaciones Biologicas Del Noroeste

Carolina Galván-Tirado

Centro de Investigaciones Biologicas Del Noroeste

Juan José Alvarado

Universidad de Costa Rica

Jorge Cortés

Universidad de Costa Rica

Francisco J. García-De-León

Centro de Investigaciones Biologicas Del Noroeste

See next page for additional authors

Follow this and additional works at: https://digitalcommons.Isu.edu/biosci_pubs

\section{Recommended Citation}

Paz-García, D., Galván-Tirado, C., Alvarado, J., Cortés, J., García-De-León, F., Hellberg, M., \& Balart, E. (2016). Variation in the whole mitogenome of reef-building Porites corals. Conservation Genetics Resources, 8 (2), 123-127. https://doi.org/10.1007/s12686-016-0527-x

This Article is brought to you for free and open access by the Department of Biological Sciences at LSU Digital Commons. It has been accepted for inclusion in Faculty Publications by an authorized administrator of LSU Digital Commons. For more information, please contact ir@lsu.edu. 


\section{Authors}

David A. Paz-García, Carolina Galván-Tirado, Juan José Alvarado, Jorge Cortés, Francisco J. García-DeLeón, Michael E. Hellberg, and Eduardo F. Balart 


\title{
Variation in the whole mitogenome of reef-building Porites corals
}

\author{
David A. Paz-García ${ }^{1,2}$ - Carolina Galván-Tirado ${ }^{3} \cdot$ Juan José Alvarado $^{4} \cdot$ \\ Jorge Cortés ${ }^{4} \cdot$ Francisco J. García-De-León $^{3} \cdot$ Michael E. Hellberg ${ }^{2}$. \\ Eduardo F. Balart ${ }^{1}$
}

Received: 12 October 2015/Accepted: 21 March 2016/Published online: 24 March 2016

(C) Springer Science+Business Media Dordrecht 2016

\begin{abstract}
The study of complete mitochondrial genomes (mitogenomes) revealed different gene rearrangements, highly variable markers, and delineated clades that have aided the understanding of the evolutionary history in corals. In this study, we examined mitogenomic variation of reef-building Porites corals and designed 34 primer pairs to target high diversity regions and to amplify the complete mitogenome of a widely-distributed Indo-Pacific species of Porites (P. lobata) and two endemic species of the Eastern Pacific (P. sverdrupi and P. panamensis). All primer pairs amplified for each species and the mitogenomes assembled yielded the same gene order as obtained from next-generation sequencing. Mitogenomic variation in Porites corals was three to ten times higher than in Acropora or Pocillopora, two other major reef builders. In contrast to these corals, the nucleotide variation in Porites species was distributed evenly along the mitogenome. Primers designed here are useful to amplify regions with the highest variation possible as well as to assemble the
\end{abstract}

Eduardo F. Balart

ebalart04@cibnor.mx

1 Laboratorio de Necton y Ecología de Arrecifes, Centro de Investigaciones Biológicas del Noroeste (CIBNOR), Calle IPN 195, Col. Playa Palo de Santa Rita Sur, 23096 La Paz, B.C.S., Mexico

2 Department of Biological Sciences, Louisiana State University, Baton Rouge, LA 70803, USA

3 Laboratorio de Genética para la Conservación, Centro de Investigaciones Biológicas del Noroeste (CIBNOR), Calle IPN 195, Col. Playa Palo de Santa Rita Sur, 23096 La Paz, B.C.S., Mexico

4 Centro de Investigación en Ciencias del Mar y Limnología (CIMAR), Universidad de Costa Rica, San Pedro, San José 11501-2060, Costa Rica whole mitogenomes of different Porites species. The resulting mitogenomes should improve our understanding of evolutionary relationships, delimitation of species, and conservation within the genus Porites.

Keywords Mitochondrial genome - Porites corals · Eastern Pacific $\cdot$ Scleractinian corals

The animal mitochondrial genome (mitogenome) generally exhibits several characteristics that make it suitable for phylogenetic analysis: high substitution rate, maternal inheritance, and lack of recombination. In contrast, most of the mitochondrial genes studied in Class Anthozoa (i.e. anemones, corals and sea pens) show slow rates of nucleotide substitution, sometimes yielding few or no differences between closely related species (Shearer et al. 2002; Hellberg 2006; Prada et al. 2014). However, the recent study of the complete mitochondrial genome in this group have revealed different mitochondrial gene rearrangements (Lin et al. 2014; Figueroa and Baco 2015), the discovery of some variable mitochondrial markers (Flot and Tillier 2007; Luck et al. 2013), and congruence between mitochondrial and morphological groups of species (Luck et al. 2013; Schmidt-Roach et al. 2014) have helped in the understanding of their evolutionary history (Medina et al. 2006; Lin et al. 2011, 2014). Levels of mitogenomic variation appear to differ among coral genera due to gene rearrangements, high diversity regions, and the presence of indels (Flot and Tillier 2007; Luck et al. 2013, 2015)

Porites is one of the most taxonomically challenging and ecologically important genera of reef-building corals (Veron 2000; Forsman et al. 2009). Although these corals can grow under many environmental conditions, brooding 
Table 1 Primer information to amplify regions with the highest variation and to ensemble the complete mitogenome in Porites corals

\begin{tabular}{|c|c|c|c|c|c|c|}
\hline & $\begin{array}{l}\text { Primer } \\
\text { order }\end{array}$ & $\begin{array}{l}\text { Primer } \\
\text { name }\end{array}$ & Mitogenome region & $\begin{array}{l}\text { Position genome } \\
\text { (NC_008166) }\end{array}$ & Primer sequences $\left(5^{\prime}-3^{\prime}\right)$ & $\begin{array}{l}\text { Product } \\
\text { size }(b p)\end{array}$ \\
\hline \multirow[t]{2}{*}{$\bullet 01$} & $1-1$ & 01_S & ND1 & $847-1554$ & F: CAGGTAACAAAATTGGAGGT & 707 \\
\hline & & & & & R: AGAGCCAACACACAATAGAA & \\
\hline \multirow[t]{2}{*}{02} & $1-2$ & 02_O & ND1-CYTB & $1377-2304$ & F: AGGGGTTTTGTATATTTTGG & 927 \\
\hline & & & & & R: AAGCACCCTGTTATGATCTG & \\
\hline \multirow[t]{2}{*}{03} & $2-2$ & 03_F & ND1-CYTB & $1997-2953$ & F: CTAGTGTTCTTTTGGGGTTT & 956 \\
\hline & & & & & R: CACTGGAGTTACCAACGAG & \\
\hline \multirow[t]{2}{*}{$\bullet 04$} & $3-3$ & 04_I & CYTB & $2657-3586$ & F: TTTAGTGTCTCTGGGGCTAC & 929 \\
\hline & & & & & R: CCATTATACCCAACGTCAAA & \\
\hline \multirow[t]{2}{*}{05} & $4-4$ & 05_A & CYTB-ND2 & $3202-4102$ & F: AATTGGGCAGTTAGTCTCTC & 900 \\
\hline & & & & & R: CCGTAAATCCACACAATAAA & \\
\hline \multirow[t]{2}{*}{06} & $4-5$ & 06_A & ND2 & $3803-4787$ & F: AAAAGCTAATTTTCCCAAAG & 984 \\
\hline & & & & & R: TAATAGACACCAGCCACAAC & \\
\hline \multirow[t]{2}{*}{07} & $5-5$ & 07_N & ND2-ND6 & $4304-5451$ & F: TTGGTTATTTTTCTATTTTGGTT & 1147 \\
\hline & & & & & R: CGCCTCCATATTTTGATACT & \\
\hline \multirow[t]{2}{*}{08} & $5-6$ & 08_A & ND2-ND6 & $4918-5900$ & F: GGATTTACAATGCTCTCTCC & 982 \\
\hline & & & & & R: AATACTTTAACCCCTCAGACC & \\
\hline \multirow[t]{2}{*}{$\bullet 09$} & $6-6$ & 09_I & ND6-ATP6 & $5597-6597$ & F: TTCAAACAAGTCGGTAAAAA & 1000 \\
\hline & & & & & R: ATTAAGAGCCCATTTAGCAG & \\
\hline \multirow[t]{2}{*}{10} & $6-7$ & 10_D & ATP6-ND4 & $6070-7359$ & F: TAGTGTTTTTATGCCGAGTG & 1289 \\
\hline & & & & & R: GAAGCCAAATATGAAATGGT & \\
\hline \multirow[t]{2}{*}{11} & $7-7$ & 11_P & ND4 & $7187-8010$ & F: ATCGGTGTTTATGCTTTTG & 823 \\
\hline & & & & & R: CCCGCCTATTTAAGTCTCT & \\
\hline \multirow[t]{2}{*}{$\bullet 12$} & $7-8$ & 12_A & ND4-12S rRNA & $7318-8356$ & F: TAGCGGTTAAAATTCCTCAA & 1038 \\
\hline & & & & & R: AGTGAAAATGTGGCTCCTAA & \\
\hline \multirow[t]{2}{*}{13} & $8-8$ & $13 \_\mathrm{Z}$ & ND4-12S rRNA & $8061-8966$ & F: TTTCCTTTTGTACTCATAGACC & 905 \\
\hline & & & & & R: ACCTGACTTCATCCAATAGAC & \\
\hline \multirow[t]{2}{*}{14} & $8-9$ & $14 \_S$ & 12S rRNA-COX3 & $8412-9521$ & F: TTTGTGCAATATACGAAAGTAA & 1109 \\
\hline & & & & & R: CAAAAGAGGTCAAGGAGAAG & \\
\hline \multirow[t]{2}{*}{15} & $9-9$ & 15_A & 12S rRNA-COX3 & $9066-9900$ & F: GGAATATAACGGAAAGTTGG & 834 \\
\hline & & & & & R: AAGTAACAGTACCCCCAGAA & \\
\hline \multirow[t]{2}{*}{$\bullet 16$} & $9-10$ & 16_N & $\mathrm{COX} 3-\mathrm{COX} 2$ & $9707-10859$ & F: TGGAATGCTTTTATTTATACTCTC & 1152 \\
\hline & & & & & R: CATCCATTTTTACACCCAAG & \\
\hline \multirow[t]{2}{*}{17} & $10-10$ & 17_C & COX2-ND4L & 10429-11164 & F: TGTTATTGTAGTAGTAGTGTTGTGG & 735 \\
\hline & & & & & R: TAAAATGCCCTCTATTAAGAAC & \\
\hline \multirow[t]{2}{*}{18} & $10-11$ & 18_H & COX2-NAD4L-ND3-ND5 & $10908-11958$ & F: GGACGTTTTATGGTCAATGT & 1050 \\
\hline & & & & & R: TAAAGCAAATGGAGCTTGTT & \\
\hline \multirow[t]{2}{*}{19} & $11-11$ & 19_E & ND3-ND5 & $11415-12217$ & F: GGTCTTTTCGTTTTATTGGT & 802 \\
\hline & & & & & R: CCССCATCTTTCTTATATCTT & \\
\hline \multirow[t]{2}{*}{ •20 } & $12-12$ & 20_Z & ND5-tRNA-Trp-ATP8- & $12160-13510$ & F: AGTGCGGGGTCTGTTATT & 1350 \\
\hline & & & COX1 & & R: ACGTACCAATGTCTTTATGGT & \\
\hline \multirow[t]{2}{*}{21} & $13-13$ & 21_M & ND5-tRNA-Trp & $12035-13044$ & F: AAGTTATTGCTTATTCGACTTG & 1009 \\
\hline & & & & & R: TTGAAGGCTAACGGTCTACT & \\
\hline 22 & $13-14$ & 22_I & ND5-tRNA-Trp-ATP8- & $12637-13552$ & F: GCGGTGTTAGTTATTGTTCTT & 915 \\
\hline & & & COX1 & & R: CTGTACCGAGCATACCTG & \\
\hline 23 & $14-14$ & 23_H & ND5-tRNA-Trp-ATP8- & $12955-13612$ & F: TGGGGAGTTGTTTAGTTTTT & 657 \\
\hline & & & & & R: GATCGTCTCCTAACATAGCC & \\
\hline$\bullet 24$ & $14-15$ & 24_E & COX1 & $13476-14389$ & F: GGCGTTTTCTACTAACCATAA & 913 \\
\hline & & & & & R: AGCAGGACAAAGCTCAAA & \\
\hline
\end{tabular}


Table 1 continued

\begin{tabular}{|c|c|c|c|c|c|c|}
\hline & $\begin{array}{l}\text { Primer } \\
\text { order }\end{array}$ & $\begin{array}{l}\text { Primer } \\
\text { name }\end{array}$ & Mitogenome region & $\begin{array}{l}\text { Position genome } \\
\text { (NC_008166) }\end{array}$ & Primer sequences $\left(5^{\prime}-3^{\prime}\right)$ & $\begin{array}{l}\text { Product } \\
\text { size (bp) }\end{array}$ \\
\hline 25 & $15-15$ & 25_R & $\mathrm{COX} 1$ & $13837-14689$ & $\begin{array}{l}\text { F: ACGGTTTATCCTCCTCTATCT } \\
\text { R: AAAGCCTCTGACACCATAA }\end{array}$ & 852 \\
\hline$\cdot 26$ & $15-16$ & 26_M & $\mathrm{COX} 1$ & $14484-15500$ & $\begin{array}{l}\text { F: ATCAGTGGGAAACTAAGACC } \\
\text { R: TACAACTCCAGTCAAACCAC }\end{array}$ & 1016 \\
\hline 27 & $16-16$ & 27_O & $\mathrm{COX} 1$ & $14701-15614$ & $\begin{array}{l}\text { F: TTCAATCTGGCGTAGTGTAG } \\
\text { R: AAAATAAAACCCACCAAAAA }\end{array}$ & 913 \\
\hline 28 & $16-17$ & 28_S & COX1-tRNA-Met-16S rRNA & $15192-16269$ & $\begin{array}{l}\text { F: AGTGATGAAAAGTAAATGAAAAA } \\
\text { R: GTCTCCGCATTGAAACAC }\end{array}$ & 1077 \\
\hline 29 & $17-17$ & 29_A & Cox1-tRNA-met-16S rRNA & $15792-16751$ & $\begin{array}{l}\text { F: TCTTTGGGCTCTACTATTTCA } \\
\text { R: GAAAACCAGCTATCTCCAAG }\end{array}$ & 959 \\
\hline$\bullet 30$ & $17-18$ & 30_H & 16S rRNA & $16452-17345$ & $\begin{array}{l}\text { F: TGAAGGAAAGTTGAAAGAGAC } \\
\text { R: GCGTTTATTATTATCACCCATC }\end{array}$ & 893 \\
\hline 31 & $18-18$ & 31_I & 16S rRNA & 16901-17796 & $\begin{array}{l}\text { F: TTTAAGGGGGATAGACTTTG } \\
\text { R: AAGCCACATAAGTTTCCAGT }\end{array}$ & 895 \\
\hline 32 & $19-19$ & 32_J & 16S rRNA & $17678-18268$ & $\begin{array}{l}\text { F: ACGAGGGTCTCACTGTCTT } \\
\text { R: TGTTACCACGCTTTTAACTC }\end{array}$ & 590 \\
\hline$\bullet 33$ & $20-20$ & 33_A & 16S rRNA-ND5 & $18214-173$ & $\begin{array}{l}\text { F: TTGGTCTGTTCGTCCATT } \\
\text { R: TGTGTCGTAGAAAAACTTAAAAC }\end{array}$ & 609 \\
\hline 34 & $20-1$ & $\left.34 \_=\right)$ & ND5 & $66-991$ & $\begin{array}{l}\text { F: ATTAGGAGAAAAAGGTGCTG } \\
\text { R: ATAAAGTAGAATCACAAAAAGTCTC }\end{array}$ & 925 \\
\hline
\end{tabular}

Annealing temperature was $54{ }^{\circ} \mathrm{C}$ for all primers. Primer numbers of first column correspond to primers from the Fig. 1c

Porites species are vulnerable to local impacts due to genetic isolation and limited capacity of dispersal (PazGarcía et al. 2012; Saavedra-Sotelo et al. 2013; Paz-García and Balart 2015). Genetic delineation of species in this group has been performed using a few nuclear markers and mitochondrial regions (e.g. control region and COI). Some such studies have sometimes found relationships congruent to morphology (Forsman et al. 2009), while others have revealed cryptic species (Boulay et al. 2014) or did not find genetic differences between named morphological species (Prada et al. 2014). Although next-generation sequencing has allowed the rapid generation of genomic resources for non-model organisms, genomic contamination may be an issue in corals due to their association with a wide variety of taxa (i.e. virus, bacterium, dinoflagellate). Thus, additional bioinformatics steps and genomic resources are necessary to screen an assembly for sequences that come only from that particular taxon (Willette et al. 2014).

The design of primers and direct sequencing of coral mitogenome could be a fast, low cost, and low risk approach if the low mitochondrial nucleotide variation in corals could be avoided. In this study, we aimed to examine the whole mitogenome variation in Porites corals, to design primers that amplify high diversity regions, and to allow future phylogenetic and phylogeographic studies to improve the evolutionary understanding of species in the eastern Pacific.

In a previous study, seventy-four primers pairs were developed to amplify the complete mitogenome in scleractinian corals (Lin et al. 2011). Here, ten primers pairs were designed to access regions with the highest variation in Porites corals and an additional twenty-four designed to assemble the whole mitogenome (see below). In total, thirtyfour overlapping primers were designed using Primer3Web (http://primer3.ut.ee) (Untergasser et al. 2012) and the recently published complete mitochondrial genomes of $P$. panamensis (NC_024182) and P. porites (NC_008166) available on the NCBI database GenBank (Medina et al. 2006; Del Río-Portilla et al. 2014). Phylogenetic breadth of the utility of these primers was tested on three Porites species collected in the Eastern Pacific: P. sverdrupi (Bahía Concepción, central Gulf of California $26^{\circ} 38^{\prime} 27.16^{\prime \prime} \mathrm{N}$, $111^{\circ} 49^{\prime} 45.89^{\prime \prime} \mathrm{W}$ ), P. panamensis (Isla Despensa, northern Costa Rica $\left.11^{\circ} 0^{\prime} 10.10^{\prime \prime} \mathrm{N}, 85^{\circ} 44^{\prime} 49.50^{\prime \prime} \mathrm{W}\right)$, and $P$. lobata (Palmitas, Gulf of Papagayo, Costa Rica $10^{\circ} 38^{\prime} 41.60^{\prime \prime} \mathrm{N}$, $\left.85^{\circ} 41^{\prime} 15.60^{\prime \prime} \mathrm{W}\right)$. One small fragment $\left(\sim 3 \mathrm{~cm}^{2}\right)$ from the center of each colony was collected in July 2011 in Mexico (sampling permit DGOPA.05356.140710.3457) and in May 2013 in Costa Rica (Resolución no. 064-2013-SINAC) and preserved in salt-saturated DMSO buffer (Seutin et al. 1991). 
Genomic DNA was isolated from each species according to protocols of the DNeasy Tissue Kit (QIAGEN, Valencia, CA, USA). Genomic DNA was amplified using each primer pair listed in Table 1. Amplifications were performed in $15 \mu \mathrm{l}$ reaction volume containing $50 \mathrm{ng}$ of template DNA, $0.4 \mathrm{mM}$ of each primer, $2 \mathrm{mM} \mathrm{MgCl}_{2}$, $0.3 \mathrm{mM}$ dNTPs, $1 \times$ PCR buffer $(10 \mathrm{mM}$ Tris-HCl, $\mathrm{pH} 8.3$, and $50 \mathrm{mM} \mathrm{KCl}$ ), and 1.5 units Taq DNA polymerase (Invitrogen Life Technologies). PCR consisted in an initial step of denaturation at $94{ }^{\circ} \mathrm{C}$ for $5 \mathrm{~min}$, followed by 30 cycles of $95{ }^{\circ} \mathrm{C}$ for $30 \mathrm{~s}, 54{ }^{\circ} \mathrm{C}$ for $30 \mathrm{~s}, 72{ }^{\circ} \mathrm{C}$ for $75 \mathrm{~s}$, and a further extension step of $72{ }^{\circ} \mathrm{C}$ for $10 \mathrm{~min}$.

All three Porites species amplified successfully using all 34 pairs of primers. PCR products ranged in size from 590 to $1350 \mathrm{bp}$ (Table 1). PCR products of $P$. panamensis were purified and Sanger sequenced (Genewiz, South Plainfield, NJ, USA). Sequences were verified and aligned in CodonCode Aligner (CodonCode Corp., Dedham, MA, USA) and compared to other coral species mitogenomes from NCBI GenBank ( $P$. panamensis NC_024182, $P$. porites NC_008166, P. okinawanensis NC_015644, P. rus NC_027526). Mitogenomic variation among Porites species was examined by estimating the nucleotide diversity and number of polymorphic sites for $300 \mathrm{bp}$ windows along the mitogenome using DnaSP v.5.10 (Librado and Rozas 2009).

The $P$. panamensis mitogenome assembled from our 34 primer pairs and Sanger sequencing (Genbank accession number KU761953) yielded the same gene order as that obtained from next-generation sequencing (Illumina MiSeq, Del Río-Portilla et al. 2014) and similar to those of other scleractinian species (Medina et al., 2006; Lin et al., 2011). In total, 335 polymorphic sites and 221 parsimony informative sites were found along the seven Porites mitogenomes. This variation was three times higher than the variation found in the mitogenoma of Acropora species (Liu et al. 2015) and ten times higher than Pocillopora species mitogenomes (Flot and Tillier 2007). In contrast to coral mitogenomes from the family Acroporidae, Agariciidae, and Pocilloporidae (Flot and Tillier 2007; Luck et al. 2013; Liu et al. 2015), nucleotide diversity and polymorphic sites in Porites species were distributed evenly along the mitogenome (Fig. 1a).

The partial mitochondrial regions used to delineate Porites species in previous studies (Control Region and COI, Forsman et al. 2009, Prada et al. 2014) represented only the $7 \%$ of the variation across the whole mitogenomes of Porites corals. This low level of variation may be why these studies failed to distinguish some Porites species from each other. The mitochondrial regions with higher variation were 16S rRNA, ND5, ND4, COX1, ND1, and CYTB. These correspond to $43.3 \%$ of the total variation in Porites mitogenome (Fig. 1b).
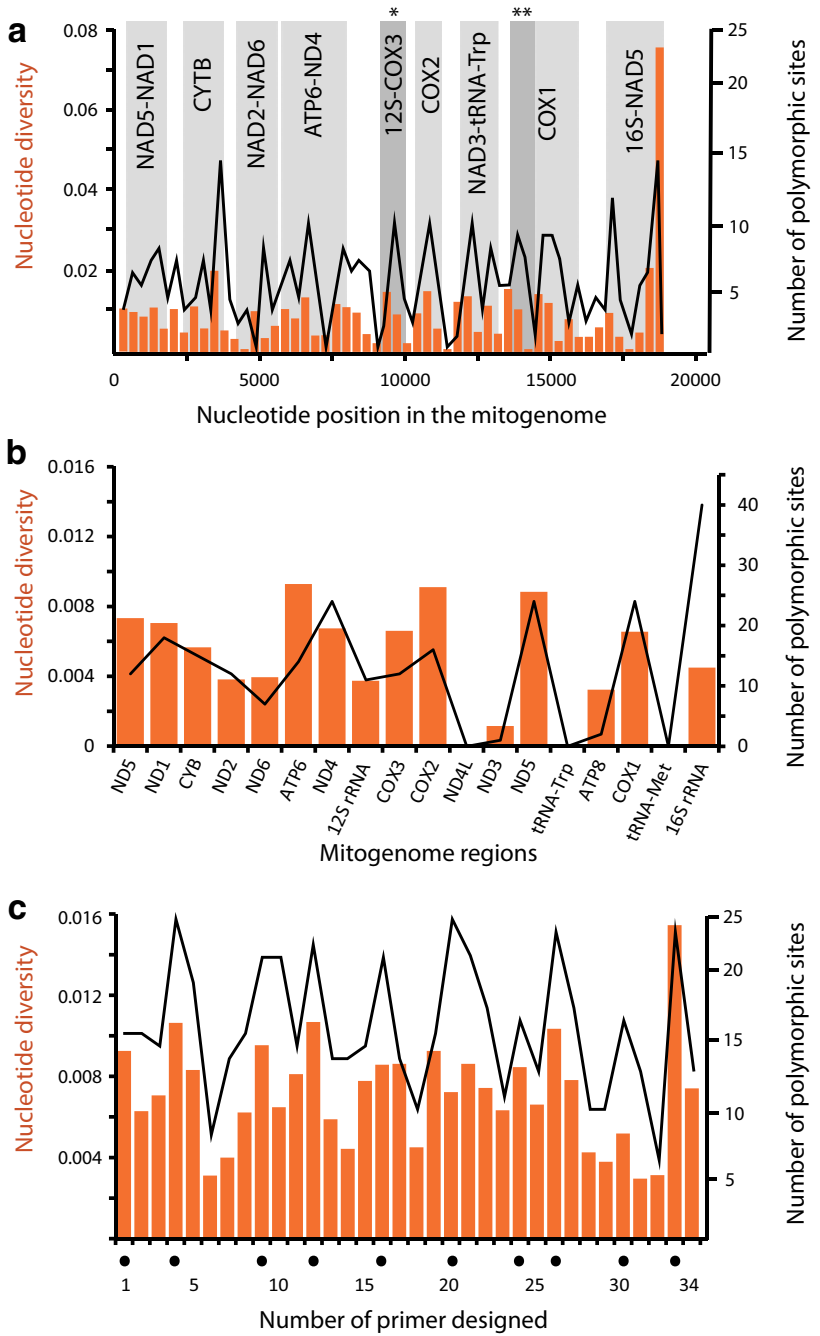

Fig. 1 Nucleotide diversity (bars) and polymorphic sites (lines) in the mitogenome of reef-building Porites corals. a Distribution of the variation in the whole mitogenome (each $300 \mathrm{bp}$ ). b Genes variation in the mitogenome $(69.25 \%$ of the total variation in the mitogenome). c Mitogenome variation accessed by primers designed in this study. Asterisks in a indicate partial mitochondrial regions used by Forsman et al. 2009 (*putative control region, **COI). Points in c indicate the ten primers that can be used to access the $64.18 \%$ of the variation in the Porites mitogenome

The primers reported here were designed to amplify regions with the highest variation as well as to aid assembly of whole mitogenomes by providing access missing regions commonly uncovered by next-generation sequencing (i.e. Liu et al. 2015). For example, just ten primers pairs (Fig. 1c; Table 1) will reveal $64.2 \%$ of the variation in the Porites mitogenome. The use of these markers will hopefully improve our understanding of evolutionary relationships, the delimitation of species, and conservation within the genus Porites. 
Acknowledgments We thank Mario Cota and Rafael Cabral of CIBNOR, Cindy Fernández, Jaime Nivia, and Kimberly García of CIMAR, Universidad de Costa Rica for field assistance. Thanks to Sofia Méndez and Noemi Bocanegra for laboratory assistance, and Gustavo Gutiérrez and Andrea Chaves for the use of equipment in the Laboratorio de Genética de la Conservación, Universidad de Costa Rica. Funding was provided by CONACYT (Grant 157993) to EFB. Vicerrectoría de Investigación, Universidad de Costa Rica (Project 808-A5-073) and Ecodesarrollo Papagayo funded the collections in Costa Rica. DAPG is a recipient of CONACYT fellowship (250126).

\section{References}

Boulay JN, Hellberg ME, Cortés J, Baums IB (2014) Unrecognized coral species diversity masks differences in functional ecology. Proc Biol Sci 281:20131580. doi:10.1098/rspb.2013.1580

Del Río-Portilla MA, Vargas-Peralta CE, Paz-García DA, Lafarga De La Cruz F, Balart EF, García-de-León FJ (2014) The complete mitochondrial DNA of endemic Eastern Pacific coral (Porites panamensis). Mitochondrial DNA 1736:1-2. doi:10.3109/ 19401736.2014.913166

Figueroa DF, Baco AR (2015) Octocoral mitochondrial genomes provide insights into the phylogenetic history of gene order rearrangements, order reversals, and cnidarian phylogenetics. Genome Biol Evol 7:391-409. doi:10.1093/gbe/evu286

Flot J-F, Tillier S (2007) The mitochondrial genome of Pocillopora (Cnidaria: Scleractinia) contains two variable regions: the putative D-loop and a novel ORF of unknown function. Gene 401:80-87. doi:10.1016/j.gene.2007.07.006

Forsman ZH, Barshis DJ, Hunter CL, Toonen RJ (2009) Shapeshifting corals: molecular markers show morphology is evolutionarily plastic in Porites. BMC Evol Biol 9:45. doi:10.1186/ 1471-2148-9-45

Hellberg ME (2006) No variation and low synonymous substitution rates in coral mtDNA despite high nuclear variation. BMC Evol Biol 6:24. doi:10.1186/1471-2148-6-24

Librado P, Rozas J (2009) DnaSP v5: a software for comprehensive analysis of DNA polymorphism data. Bioinformatics 25:1451-1452. doi:10.1093/bioinformatics/btp187

Lin M-F, Luzon KS, Licuanan WY, Ablan-Lagman MC, Chen CA (2011) Seventy-four universal primers for characterizing the complete mitochondrial genomes of scleractinian corals (Cnidaria; Anthozoa). Zool Stud 50:513-524

Lin M-F, Kitahara MV, Luo H, Tracey D, Geller J, Fukami H, Miller DJ, Chen CA (2014) Mitochondrial genome rearrangements in the scleractinia/corallimorpharia complex: implications for coral phylogeny. Genome Biol Evol 6:1086-1095. doi:10.1093/gbe/ evu084

Liu S-YV, Chan C-LC, Hsieh HJ, Fontana S, Wallace CC, Chen CA (2015) Massively parallel sequencing (MPS) assays for sequencing mitochondrial genomes: the phylogenomic implications for
Acropora staghorn corals (Scleractinia; Acroporidae). Mar Biol 6:1383-1392. doi:10.1007/s00227-015-2657-1

Luck DG, Forsman ZH, Toonen RJ, Leicht SJ, Kahng SE (2013) Polyphyly and hidden species among Hawai'i's dominant mesophotic coral genera, Leptoseris and Pavona (Scleractinia: Agariciidae). PeerJ 1:e132. doi:10.7717/peerj.132

Medina M, Collins AG, Takaoka TL, Kuehl JV, Boore JL (2006) Naked corals: skeleton loss in Scleractinia. Proc Natl Acad Sci USA 103:9096-9100. doi:10.1073/pnas.0602444103

Paz-García DA, Balart EF (2015) New record of the endemic coral Porites sverdrupi (Gulf of California): do fluctuations in seawater temperature regulate its southernmost range limit? Marine Biodiversity. doi:10.1007/s12526-015-0375-z

Paz-García DA, Chávez-Romo HE, Correa-Sandoval F, ReyesBonilla H, López-Pérez A, Medina-Rosas P, Hernández-Cortés MP (2012) Genetic connectivity patterns of corals Pocillopora damicornis and Porites panamensis (Anthozoa: Scleractinia) along the west coast of Mexico. Pac Sci 66:43-61. doi:10.2984/ 66.1 .3

Prada C, DeBiasse MB, Neigel JE, Yednock B, Stake JL, Forsman ZH, Baums IB, Hellberg ME (2014) Genetic species delineation among branching Caribbean Porites corals. Coral Reefs 33:1019-1030. doi:10.1007/s00338-014-1179-5

Saavedra-Sotelo NC, Calderon-Aguilera LE, Reyes-Bonilla H, PazGarcía DA, López-Pérez RA, Cupul-Magaña A, Cruz-Barraza JA, Rocha-Olivares A (2013) Testing the genetic predictions of a biogeographical model in a dominant endemic Eastern Pacific coral (Porites panamensis) using a genetic seascape approach. Ecol Evol 3:4070-4091. doi:10.1002/ece3.734

Schmidt-Roach S, Miller KJ, Lundgren P, Andreakis N (2014) With eyes wide open: a revision of species within and closely related to the Pocillopora damicornis species complex (Scleractinia; Pocilloporidae) using morphology and genetics. Zool J Linn Soc 170:1-33. doi:10.1111/zoj.12092

Seutin G, White BN, Boag PT (1991) Preservation of avian blood and tissue samples for DNA analyses. Can J Zool 69:82-92

Shearer TL, Van Oppen MJH, Romano SL, Wörheide G (2002) Slow mitochondrial DNA sequence evolution in the Anthozoa (Cnidaria). Mol Ecol 11:2475-2487. doi:10.1046/j.1365-294X. 2002.01652.x

Untergasser A, Cutcutache I, Koressaar T, Ye J, Faircloth BC, Remm M, Rozen SG (2012) Primer3-new capabilities and interfaces. Nucleic Acids Res 40(15):e115

Veron JEN (2000) Corals of the world. Australian Institute of Marine Science, Townsville

Willette D, Allendorf F, Barber P, Barshis DJ, Carpenter KE, Crandall ED, Cresko WA, Fernandez-Silva I, Matz MV, Meyer E, Santos MD, Seeb LW, Seeb JE (2014) So, you want to use next-generation sequencing in marine systems? Insight from the Pan-Pacific Advanced Studies Institute. Bull Mar Sci 90:79-122. doi:10.5343/bms.2013.1008 